\title{
HALK İNANIŞLARI KAPSAMINDA İNCELENEN BİR ASTROLOJİ METNİ: "DÎV-NÂME"
}

\author{
AN ASTROLOGY TEXT STUDIED WITHIN THE EXTENT OF PUBLIC \\ BELIEFS: "DÎV-NÂME"
}

\section{Duygu BINGÖL ${ }^{*}$}

ÖZ: Varoluşun başlangıcından beri gök cisimleri, yıldızlar, ay ve güneş insanoğlunun daima merak ettiği, zaman zaman tanrılaştırdığı ve ilgilenmekten hiç vazgeçemediği unsurlar olmuştur. İslamî anlayışta burçlarla ilgili her şeyin anlatıldığı eserler "Dîv-nâme, Yıldız-nâme" başlığı altında geçmektedir. Ele aldığımız Leipzig Üniversitesi Kütüphanesi'nin İslamîk El Yazmaları bölümünden alınan eser ise Hz. Süleymân ve bahsedeceğimiz burçların perileri arasında geçen konuşmaları, bu perilerin insanlara ne gibi zararlar vereceğini ve bu zararlardan korunma yöntemlerini anlatmaktadır. Her bir burca mensup peri, teker teker anlatılmış, hakkında açıklayıcı bilgiler verilmiştir. Metinde öncelikle bu perilerin isimleri verilmiştir. Ardından yaşadıkları yerler ve bazı fiziksel özellikleriyle metne konu olan bu perilerin insanlara birtakım zararlar verdiği tespit edilmiştir. Kültürümüzde hala varlığını koruyan birtakım halk inanışlarına dayalı kavramları ele alan eser, kișilere doğaüstü varlıklardan korunma yollarını, iyileşmek için okunması gereken ayetleri, yapılacak eylemleri anlatmaktadır. Muska yazmak, kurban kesmek, mum yakmak, șifalı kâğıtları bir suya atıp, bu suyla abdest almak bahsedilen korunma yöntemlerindendir. Çalışmada bahsi geçen hastalıklar ve bu hastalıklardan kurtulma yöntemleri halk inanışları bağlamında incelenmiş, barındırdığı folklorik ögelerle birlikte açıklanmıştır. Amacımız ilgili literatürde bilinmeyen yeni bir eseri gün yüzüne çıkarmak ve bu alanda yapılan çalışmalara katkı sağlamaktır.

Anahtar Kelimeler: Dîv-nâme, burç, peri, halk inanışları, Dîv-nâme Berây-ı Merdân u Zenân. ABSTRACT: Celestial bodies, stars, moon and the sun have always been the elements that human beings have always wondered, sometimes have divinised and never have given up since the beginning of existence. The works that describe everything about the horoscopes in Islamic understanding are under the title of 'Dîv-nâme, Ylldız-nâme'. The work that we have reseached which were taken Islamic Manuscripts section of the Leipzig University Library tells conversations between Hz. Süleyman and horoscopes which will be mentioned later, how will fairies harm to human and the methods of proteciton from these harms. The fairy belonging to each sign is explained one by one and descriptive information is given about it. The names of these fairies are givenprimarily in the text.Then, ,t was determined that these fairies, which are the subject of the text with their places and some physical features, caused some harm to people. The work that exemines the some based on public beliefs concepts that still exist in our culture, tells individuals the ways of protection from supernatural beings, verses to be read to recover and the action to be taken. Writing amulets, sacrificing, burning candles, throwing healing papers into water and taking ablution with this water are among the meyhods oh protectipn mentioned. The diseases mentioned in the study and the methods of recovery of these diseases are examined in the context of folk beliefs and explained with the folkloric elements they contain.

* Ankara Hacı Bayram Veli Üniversitesi Lisansüstü Eğitim Enstitüsü Türk Dili ve Edebiyatı Anabilim Dalı Lisansüstü Öğrencisi / Ankara - duyguu.bingoll@gmail.com (ORCID ID: 00000002-8700-3647)

This article was checked by Turnitin. 
Our aim is to reveal a new work that is not known in the related literature and contribute to the studies in this field.

Keywords: Dîv-nâme, horoscope, fairy, folk beliefs, Dîv-nâme Berây-ı Merdân u Zenân.

\section{Giriş}

Kültür varlığının önemli bir bölümünü olușturan halk kültürü, kuşaktan kuşağa aktarılarak günümüze kadar gelmiş değerler bütünüdür. Halk kültürü, aynı zamanda sözlü gelenekte var olan ve daima yaşatılan bütün ürünlerle beslenir. Halk kültürünün dayandığı temel nokta, içinde var olan değerler ve toplum tarafından benimsenmiş inanışlardır (Artun, 2006: IX). Resmi din öğretilerinin dışında kalan, geleneksel ve kültürel bağlamda halk arasında yaşamaya devam eden inançların bütününe halk inançları denir (Boratav, 1994: 7). Halk inançları insanların bir yönüyle problemlerine çözüm bulma, hayata anlam verme gibi ihtiyaçlarının bir ürünü olarak ortaya çıkmıştır (Kandemir, 2016: 98). Yüzyıllar öncesinde de varlığını sürdüren bazı inanışlar doğaüstü varlıklar söz konusu olduğunda insanlar üzerinde çok daha etkileyici bir konumda olmaktadırlar.

Edebiyatın temel konusu şüphesiz insandır. Ortalama beş asır boyunca toplumda temas edilmedik hiçbir yer bırakmayan Osmanlı edebiyatı, neşredilmiş eski metinler söz konusu olduğunda Türk toplumunun sosyal hayatını, halk inanışlarını, kültürel yapısını da gözler önüne sermektedir (Şentürk, 1993: 211).

Ele aldığımız eser Osmanlı sahasında yıldız ilmi çerçevesinde oluşturulmuş ve içinde çeşitli inanışları barındıran bir eserdir. Eserde kişilerin doğum tarihlerine göre belirlenen burçlar, bu burçların perileri ve perilerin insanlara ne gibi zararlar vereceği anlatılmış, birtakım halk inanışlarından bahsedilmiştir. $\mathrm{Bu}$ inanışlar verilmeden evvel dîvnâmelerden bahsetmek uygun olacaktır.

\section{Dîv-nâmeler}

Daha genel ismiyle "Yıldız-nâme" olarak bilinen dîv-nâmeler gelecekten haber veren, insanlık tarihi kadar geçmişe dayanan, çoğunlukla mensur metinlerdir. Yüzyıllardır süregelen, insanların merakını celb eden gayb âlemi, İslami anlayışta daima insan idrakinin dışında tanımlanmıştır (Gür, 2012: 203).

Burçların veya halk tabiriyle yıldızların insan üzerindeki etkisine inanmak, İslam'ın, ilahi iradeye atfettiği mutlak hâkimiyet prensibiyle çatışmaktadır. Konunun İslam inancı açısından önemli görülen diğer bir yönü de geçmiş devir ve kavimlerde görüldüğü üzere, burç ve yıldızlar gibi semavi cisimlere, müstakil bir kudret nispet eden ve onlara tapmaya varan inanışların, tevhid akidesiyle bağdaşmayışıdır (Kutluer 1992: 423). Fakat İslam kültürü içinde de burçlar ve fallar her zaman var olmuş ve bu işle pek çok âlim meşgul olmuştur. 
Çoğu dîv-nâme yeme ve içme düzeni, çocuk yaparken seçilecek gün ve saatler ile çocuğu olmayan kişilere tavsiyeler, hangi günlerde ana rahmine düşen çocuğun iyi tabiatlı, hangi günlerde ana rahmine düşen çocuğun kötü tabiatlı olacağına ilişkin hesaplamalar, sefere çıkma, ağaç dikme, ekin ekme, tırnak kesme, ata binme, kan alma ve aldırma, elbise dikme, tıraş olma, hamama girme, bina yapma, alısveriş yapma, köle alıp satma, anlaşma yapma vb. unsurlar üzerine olurken (Erciyas 2010: 46) incelediğimiz eserde bu gibi unsurlara rastlanılmamaktadır.

Dîv-nâmelerin en belirgin özelliği Süleyman peygamberin adının zikredilmesi ve Kur'an'dan alınmış birtakım ayetlerin verilmesidir. Çeşitli burçlara mensup kişilere, bu burçların perilerinden korunma amaçlı talimatlar verilir ve bu talimatlar daima bir ayet eşliğinde yapılır. Nitekim incelediğimiz eserde de bu durum söz konusudur.

Günümüzde de halk arasında önemli noktada olan burçlar, gerek İslamiyet öncesi devirlerde, gerek İslami devirde daima hayatın içinde olmuş ve insanların açıklanmaya muhtaç gördüğü konuların başında gelmiştir.

\section{Eserin Tanıtımı ve Muhtevası}

"Dîv-nâme Berây-ı Merdân u Zenân" başlığı ile kayıtlı olan eser Leipzig Üniversitesi Kütüphanesi'nin Islamî El Yazmaları bölümünden alınmıştır (URL-1).1 " Fleischer, s. 450, 3" katalog numarası ile kaydolan eserin kayıt tipi kısmında "çok metinli bir el yazmasından gelen metin" notu bulunmaktadır ve incelediğimiz kısım, yazmanın son bölümünü oluşturur. Eser mensur bir burç metnidir. Eserin yazıldığı yüzyll ve eseri neşreden belirtilmemiştir. Konu başlığı "astronomoy/astrology" şeklindedir.

Nesih yazı çeşidi ile yazılan eser 17 varaktan meydana gelmektedir. Her bir sayfada toplam 11 satır bulunan eserin yazısı oldukça okunaklıdır.

Her ne kadar yüzyılı belirtilmemiş olsa da Eski Anadolu Türkçesi özelliklerini taşıdığı görülmektedir. "birle, kangı, kande, sünük" vb. öz Türkçe kelimelerin sıklıkla kullanıldığı eserin dilinin sade olduğunu ve eserin Arapça- Farsça tamlamalardan uzak bir şekilde kaleme alındığını söylemek hata olmaz.

Eser kendi içinde toplam 12 bölüme ayrılmıştır. 1. bölüm "Hamel/Koç" burcuyla başlamakta ve diğer burçlar, ayların sıralamasına göre günümüzle paralel bir şekilde gitmektedir. Eserde önem arz eden unsur burç adlarının ve bunlarla ilişkili gezegenlerin Arapça verilmiş olmasıdır.

Eserin başlangıç kısmı ve gelişen bazı olaylar Firdevsî̀nin Tâli i Mevlûd adlı eserine benzemektedir. Fakat burçlar hakkında verilen bilgiler ve burçların perilerinin isimleri Tâlici Mevlûd'dan farklılık göstermektedir. Ayrıca Tâli'i Mevlûd'un sonunda 12 Hayvanlı Türk takvimi de yer almaktadır.

\footnotetext{
${ }^{1}$ https://www.islamic-manuscripts.net/receive/IslamHSBook_islamhs_00000786
} 
Eserin başlangıcı ve olay akışı şu şekildedir: Hz. Süleyman Peygamber, eşi Belkıs'la birlikte tahtında oturmaktaydı. Ansızın içeri telaş içinde bir yaşlı adamcağız girdi. Selam verdi ve konuşmaya başladı: "Ey Süleyman Hazretleri! Ben 350 yaşında bir pîrim. Allah Te'alâ bana bir oğul verdi. Evimin yakınlarında virâne bir yer vardır. Oğlum diğer küçük çocuklarla oynamak için o eve gitmiş. Fakat bir baktım ki oğlumun bir eli ve bir ayağı tutmuyor. Sordum, soruşturdum ki sana beyat eden perilerden birisi yapmış bu işi. Bu ahval benim gibi zavallı bir yaşlı adama mubah mıdır?" dedi. Bu durumun üzerine Süleyman Peygamber cinlerin ulularını yanına çağırdı. Ve dedi ki: "Ey cinler ve periler uluları! Sizler nerelerde yaşarsınız, yurdunuz neresidir? İnsanlara ne gibi kötülükler yaparsınız? Ve insanlar bu kötülüklerden nasıl kurtulup, eski sağlıklarına kavuşurlar? Eğer doğru cevap vermezseniz hepinizi atește yakarım, size türlü türlü belalar ederim." Bunun üzerine 12 cin haberi ișitip ağladılar. "Ya Resûlullah! Eğer bildiklerimizi sizden gizlersek bize istediğinizi yapın. İște bildiklerimiz bunlardır:" diyerek her cin ait olduğu burcu, nerede yaşadıklarını, bu burçtan olan kimselere ne gibi zararlar vereceklerini ve bu zararlardan korunma yollarını anlatmaya başlarlar. Așağıda bu konuşmaların metin içindeki orijinal şekli verişmiştir.

"rāvịler şöyle rivāyet itmişlerdir kim bir gün süleymān peyġamber 'aleyhis-selām sa‘ādet taḥtında oturmışdı ve helāli belḳıs yanında idi. nāgāh bir pịr içerü girdi. selām virdi ve eyitdi: "yā nebịyu'l-lāh benim “ömrim üç yüz elli yıl oldı. allah-te ālā baña bir og̉ul virdi” didi. ve bir nāresịde og̉lāncığı o günde ḳodı. feryād eyledi. eyitti: "evim yanında bir vịrān yer vardır. og̉lancığım anda varup og̉lancıklar ile oynar. nā-gāh anı bilürüm. Bir eli ve bir ayaġı dutmaz olur. șordum ve buldum ki senüñ kullaruñdan ḩatā erişmiş imdi revā mıdır ki zamānında bir pịre żulm ola" didi. öyle diyicek süleymāñ peyġamber 'aleyhi's-selām dịvler uluların yanına oḳudı. ve eyitti. "ey cịnnler ve periler uluları baña țog̉rı cevāb virüñ kim her biriñüñ maḳāmı ne gibi yerde olur ve ādem og̉lānı sizüñ üzerüñüze gelüp rencįde edicek ne fíl idersiz ve oña ne çāre olur kim ol ficlden halāṣ olup gerü șị̣hat bula. Eger țog̉rı dimezseñüz sizi dükili ta`alluḳatuñuz ile oda yaḳarum. size dürlü dürü belalar iderim.” didi. çünkim bu on iki dịv bu haberi işitdiler. zāruluk idüp eyitdiler kim yā resūlullah! eger bildigümizi hażretiñden gizlersüz her ne kim emriñüzdür öyle idüñ didiler"

Eserde adı geçen on iki burca mensup kimselerin karakteristik yahut fiziksel özelliklerinden bahsedilmemekte, periler tarafından uğrayacakları felaketler ve sağaltma yöntemleri üzerinde durulmaktadır. Bu haliyle eserin halk inanışları bağlamında incelenmesi kaçınılmaz olmuştur. Muska yazmaktan, kurban kesmeye, mum dikmekten, dua gömmeye kadar pek çok 
inanışın kendisine yer bulduğu eser Dîv-nâme türünün ilgi çekici bir örneğidir. Çalışmamızın sonuna eserin tamamı eklenmiştir.

\section{Dîv-nâme'de Bahsi Geçen Perilerin İnsanlara Verdiği Zararlar ve Bunlardan Korunma Yolları İle İlgili İnanışlar}

\subsection{Perilerin Verdiği Zararlar}

Eserde her bir perinin öncelikli olarak mensup olduğu burç ve adı verilmiştir. Bu periler teker teker nerelerde yaşadıklarını, kendi burcundan olan insanlara, Allah'ın adını zikretmeksizin yanlarına geldiklerinde ne gibi zaralar vereceklerini anlatırlar. Kültürümüzde "besmele"siz ıssız yerlerde dolaşılmaması, geceleri hamamlar, virane yerler, değirmenler, ormanlar gibi ürkütücü yerlerde bulunulmaması gerektiği gibi yaygınlaşmış inanışlar mevcuttur. Aksi takdirde cinlerin gazabına uğranılacağı düşünülür. Eserde tamamen bu inanış üzerinde durulmuştur.

Her bir burcun perisi, ait olduğu burcun kişisine farklı farklı eziyetler eder. Örneğin Hamel yani Koç burcunun perisi Yahya bin Leys su kenarlarında ve ıssız yollarda yaşar. Allah'ın adını anmadan yanından geçen kimselere kuvvetli bir rüzgâr gibi eseceğini, gözlerini karartacağını, yanlarını ağrıtacağını, gönlünü bulandıracağını, onu adeta bir ateş parçassı haline dönüştüreceğini, yemek yiyemez, uyku uyuyamaz hale geleceğini başına gelen felaketleri kimseye anlatamayacağını açıklar: Başı aǵrur. Gözleri kararur. Ve göñli bulanur. Yanları ziyāde ag்rur. Bir pāre od olur.

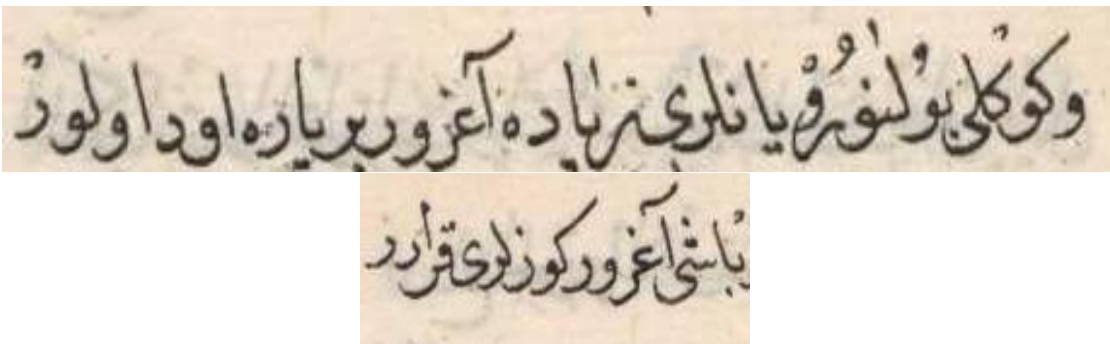

Sevr yani Boğa burcunun perisi ise Nil Denizi'nde yaşayan fakat kuş misali tüm dünyayı dolaşan Haynanuş'tur. Haynanuş'un insanlara verdiği zararlar şu şekildedir: Nişānı oldur kim gövdesi ditrer ve yüzi dutuşur sünigi baǵı çözilür. İki ayag்ı üzerine dönemez ve kendüye fermānsuz olur. Ve 'aḳlı zā’ịl olur. Bilekler ța ām yimez yüregi kıızar çok șu içer vardukça zaḥmet artar.

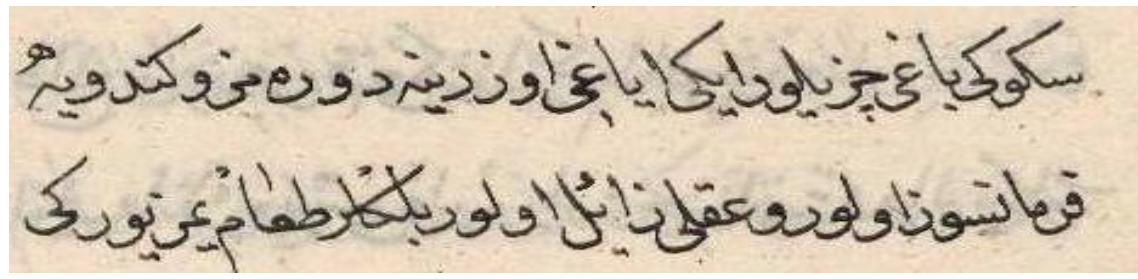

Esed (Aslan) burcunun perisi Mafhsa bin Zeyned ise pinarlar ve dere kenarlarında yaşar. İnsanoğluna yaptığı kötülükler şunlardır: Nişānı oldur 
kim yüregi șancır ve arkası aġrur ve başı bile ve baldırı ag̉rır. Hịc țākati kalmaz .Gāh hoş gāh nā-ȟoş olur, yerinden țuramaz olur.

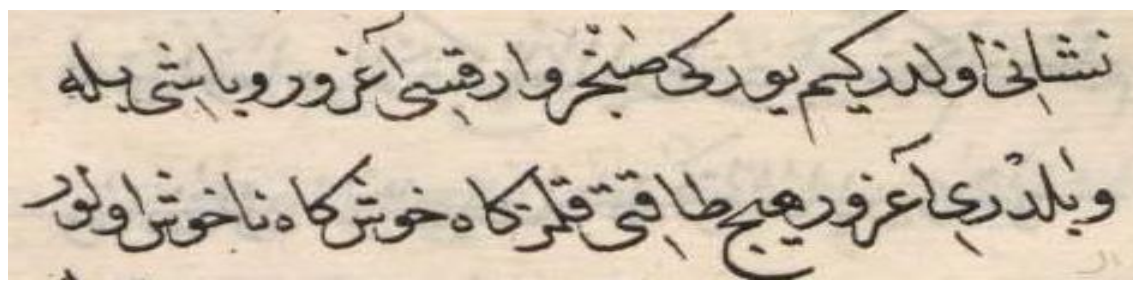

Devl yani Kova burcunun perisi Keşâkâtü yemiş ağaçlarının dibinde ve ekin biten tarlalarda ikamet eder. Makamına Allah adını zikretmeden gelenlere şu kötülükleri yapar: Ben aña yelüm birle toḳunurum. Nişāñı oldur kim yiyecek yemez cümle sünükleri ag̉rur. Tamarlarına yel țolar, içi yanar. Șuyı çok içer ve cümle endāmları süst olur.

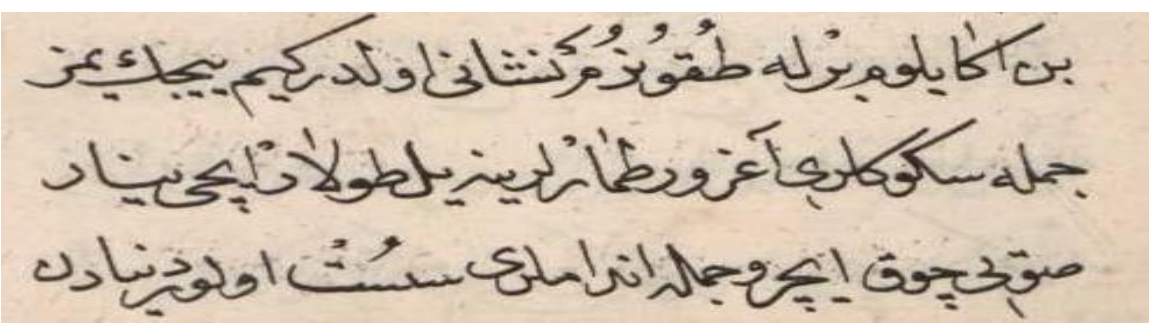

Eserde, genel itibariyle burçların perileri, insanlara, aynı türden zararlar vermektedir. Çoğu burca mensup insanların başına gelen ya da gelecek olan felaketler aynıdır. Bu sebeple ara başlıklar altında bütün burçları vermek yerine, başlıklara verdiğimiz isimlere göre, her bir başlık altında, ön plana çıkan burçları seçtiğimizi belirtmek isteriz.

\subsection{Perilerin Suretine Büründüğü Hayvanlar}

Kültürümüzde ve inanışlarımızda kendisine kutsiyet yüklenen hayvanlar olduğu gibi, uğursuz olarak addedilen, korkulan ve sakınılması gereken hayvanlar da vardır. Türk inanç sistemlerinde ve İslamiyet etkisiyle oluşan Türk kültür çerçevesinde, hayvanlara yüklenen olumlu ve olumsuz anlamlar, sözlü kültür ürünleri aracılığıyla, yüzyıllar boyunca aktarılmakta, edebi eserlere konu olmaktadır ( Sinmez- Aslım, 2017: 207).

Dîv-nâme'de geçen beş burçta, perilerin insanlara hayvan suretinde görünmesi durumu söz konusudur. Bunlardan Sevr (Boğa) burcu perisi Haynanuş kuş, Seretân (Yengeç) burcu perisi Meymûn kaplumbağa, yılan, kirpi ve tavşan, Esed (Aslan) burcu perisi Zeyned yılan ve kurbağa, Mizân burcu perisi Vezîrât çekirge ve son olarak Hut (Balık) burcu perisi yılan suretine girerek insanların karşısına çıktığı görülür.

Kaplumbağa genel olarak uzun ömür ve bolluğun sembolüdür fakat şanssızlık ve sıkıntıyı temsil ettiği de görülür. (Çatalbaş, 2011:53) Yılan ve kirpi de hem olumlu hem olumsuz anlamlar çağrıştırır. Tavşan, Türk kültüründe bolluk ve kurnazlığı temsil ederken bazı mezheplerde 
uğursuzluk getirdiğine inanılır. Seretân burcunda bu hayvanlar şu şekilde geçmektedir: Yā yılan ya kablubaġa ya kirpi yā țavşan gibi görünürüm. Ol benim heybetimde uyumaz çaġırur.

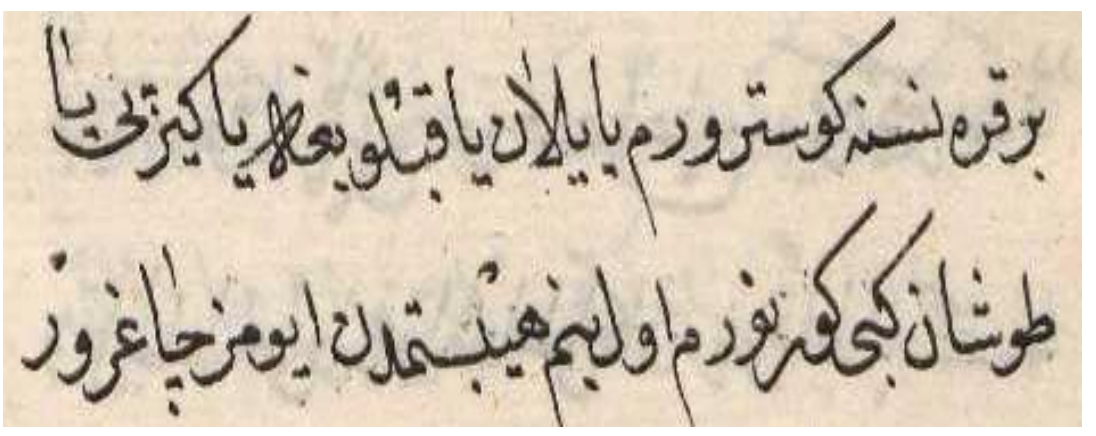

Eserde dikkat çeken bir diğer hayvan ise Mizân burcunda "çetik" ismiyle geçen çekirgedir. Kültürümüzde herhangi bir felaketten önce çekirgelerin sustuğuna ve çekirge öldürmenin uğursuzluk getireceğine inanılır. Mizân burcu perisi Vezîrât için, "Bu burçtan olan kimse Allah adını anmadan yanıma gelirse bir çekirge kılığına girip ona seslenir yanıma getiririm." ifadeleri kullanılmıştır.

Bahsi geçen hayvanların inanışımızdaki yerleri ve fonksiyonları incelendiğinde, bu hayvanların eserde periler aracılığıyla kişilere olumlu șeyler çağrıştırdığı, perilerin bu hayvanların şans yönünü kullanarak kişileri yanlarına çektikleri tespit edilmiştir.

Kültürümüzde önemli bir yere sahip olan baykuşun eserde yer almadığını görüyoruz. Uğursuzluğu ve ölümü temsil ettiğine inanılan baykuşun, olumsuz özelliklere sahip periler arasında kendine yer bulamaması dikkate değerdir.

\subsection{Perilerin Verdikleri Zararlardan Korunma Yöntemleri}

\subsubsection{Kurban Kesme}

Kurban kesme ritüeli, İslam dininin doğuşundan çok önceki çağlara kadar uzanır. Çok eski tabiat dinleri ile Mezopotamya, Anadolu, Mısır, Hint, Çin, İran ve İbrani dinlerinde de kurban adama geleneğinin olduğu bilinmektedir (Bekki, 1996: 17). Tabiatüstü güçlere yaklaşma, onlardan bir şey dileme ya da günahlardan korunma amacıyla kurbanlar kesilir (Güç, 2002: 434).

Ele alınan eserde hemen hemen her burçta insanlara perilerin verdiği zararlardan korunmak için kurban kesmeleri tavsiye edilmektedir. Hamel (Koç), Cevzâ (İkizler), Esed (Aslan), Sünbüle (Başak), burçlarından olan kimselerin kara koyun ya da kuzu, bunlar bulunmazsa karatavuk kurban etmeleri gerektiği söylenmektedir. Sünbüle burcunda: "Dermānı oldur kim bir kara koyun kurbān ideler. Eger bulunmazsa bir kara kuzı yā bir kara tavuk" şeklinde geçmektedir. 


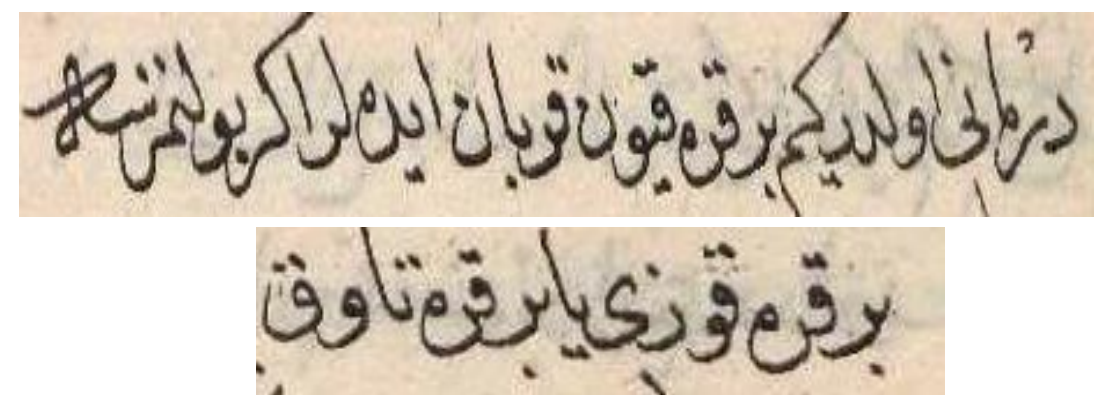

Mizân (Terazi)'da ak oğlak; Kavs (Yay)'da alaca koyun, o bulunmazsa alaca tavuk; Delv (Kova)'de gök koyun, yoksa gök kuzu, o da yoksa gök horoz; Hut (Balık)'da ise ak koyun, ak kuzu o da yoksa ak horoz kurban edilmesi tavsiye edilmektedir.

Eserde kurban edilen hayvanlarla ilgili dikkat çekici bir unsur yer almaktadır. Bu hayvanlar kesilirken, tıpkı onlar gibi ses çıkarılması gerektiği söylenmektedir. Bu durum tüm kurban edilen hayvanlar için geçerlidir. Örnek verecek olursak Cevzâ (İkizler) burcu için: Koyun öykünle afg̉urmak gerek." ifadesinin geçtiği görülmektedir.

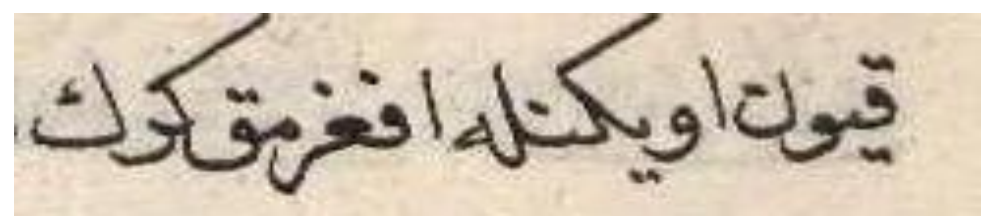

\subsubsection{Muska Yazma}

Çoğunlukla insanlar tarafından taşınan, bazen de belli mekânlara yerleştirilerek ya da gömülerek kötü güçlerin etkisinden koruma sağladığı kabul edilen muska, pek çok inançta yaygınca görülen büyü ile yakından alakalı kült nesnelerden biridir (Demirci, 2006: 265). İslam kültüründe kişileri cinlerin şerrinden korumak amaçlı muska, cevşen gibi koruyucu dualar yazılır. Eserde bir önceki bölümde açıklanan kurbanların kanı ile "beti" adı altında geçen muskalar yazılması tavsiye edilmektedir. Muskaların bazı burçlarda kan ile değil müşk ve safranla yazılması gerektiği belirtilmiştir. Yazılacak olan muskaların sayısı değişiklik göstermektedir. Kimi yerde en az iki en çok dört muska yazılması söylenip bu muskalarla çeşitli eylemler yapılması da istenmiştir. Muskayı suya atıp içme, muskayı başında gezdirme, yıkanılacak suya koyma, dört yol ağzına atma, suya bırakma ve gömme bu eylemlerden bazllarıdır. Mizân burcunda bahsedilen muskalardan birinin insan suretli bir kâğıt keserek onun üzerine yazılması talimatı verilmiştir. Yapılacak eylemlerin her biri için dualar verilmiştir. Bazı burçların sonuna çeşitli tılsımlar da eklenmiştir. Örneğin Akreb burcu için: Üç beti yazalar. Müşkle za'ferānla birin götüre ve birüñ üç gün șuyın içe ve biriyle yā yı kana ve başı üzerinde Tañrı adın oḳıyalar. İçecegi budur șeklinde açıklama yapılmıștır. 

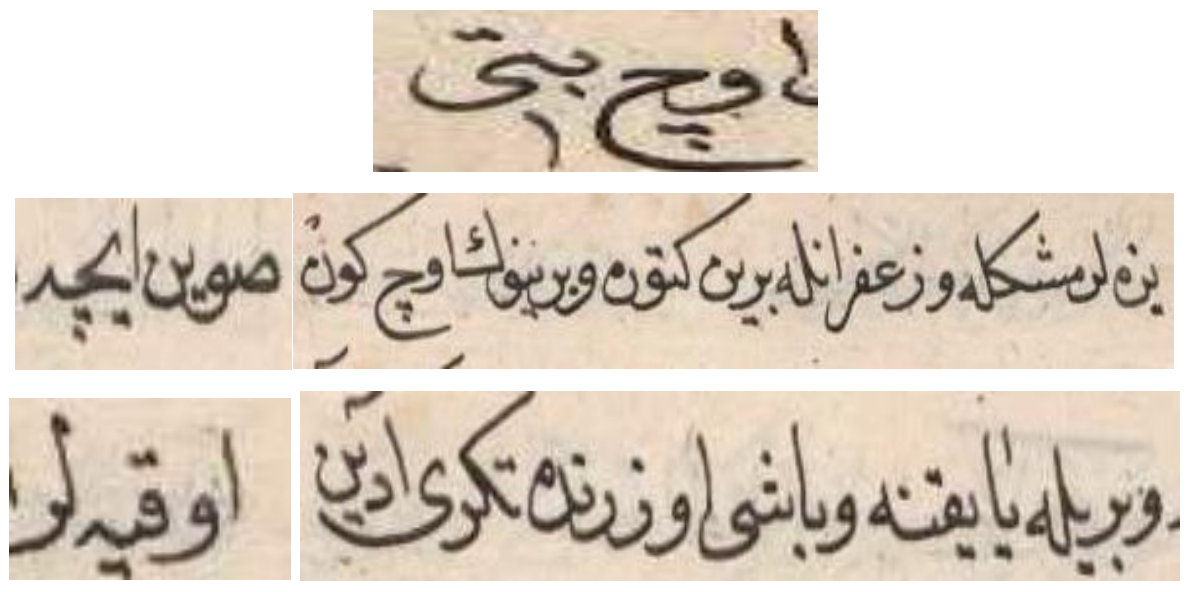

Bütün dualar, yapılacak eylemler doğrultusunda "içeceği budur, götüreceği budur, yunacağı budur, gömeceği budur" șeklinde tarif edilmiştir.

Esed (Aslan) burcundan bir tılsım örneği:

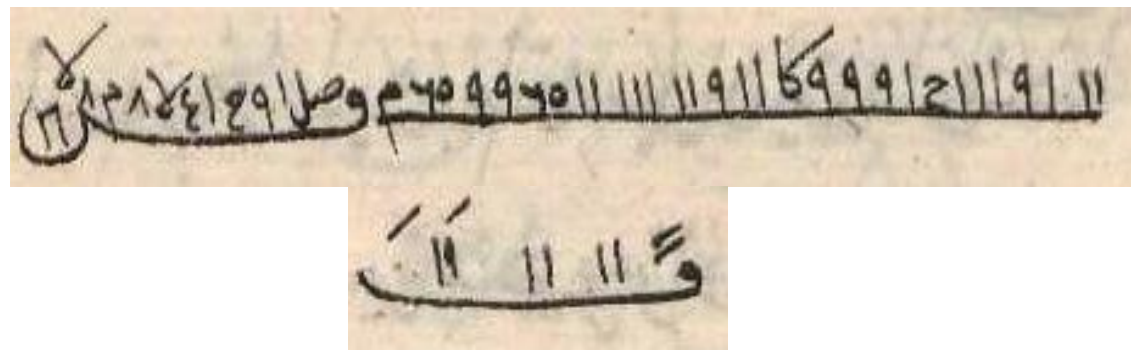

\subsubsection{Mum Yakma}

Eserde mum yakma hadisesine yalnızca Cedî (Oğlak) burcunda rastlanmıştır. Kültürümüzde çeşitli adakların gerçekleşmesi için kutsal mekânlarda mum yakma/mum dikme âdeti vardır. Mezar taşlarına mum yakıp dikme, türbelere mum dikme çok eskiden beri görülen inanışlarımızdandır. Toplumumuzda İslamiyet'ten önceki devirlerden beri ateşe bir kutsiyet yüklendiği için yakılan mumun istenilen dileğin çabuk gerçekleşmesine yardımcı olacağı düşünülür. Aslında mum yakma bir nevi sözsüz dua timsalidir. Eserde geçen mum yakma hadisesi ise bir mekânda değil bizzat kişinin gövdesinde yakılacaktır: Gövdesinde beş yirde mum yakalar. Birin başında ve birin bazusunda ve ikisin iki dizinde.

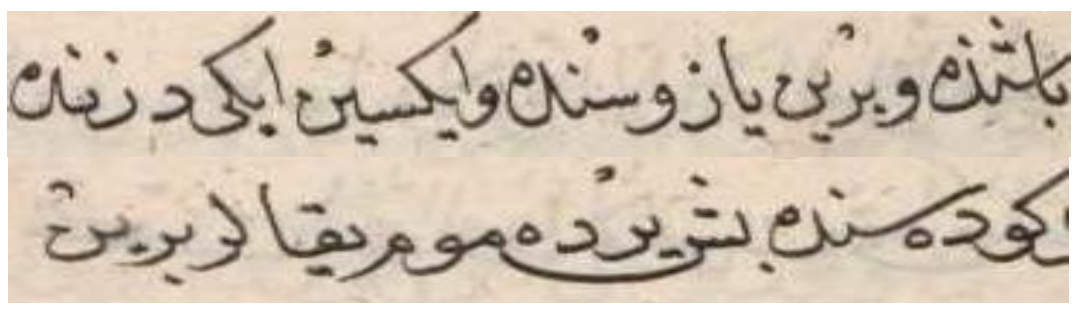




\subsubsection{Gusül Abdesti Alma}

Eserde sadece Hut (Balık) burcunda gusül alma hadisesi mevcuttur. Hut burcunun perisi Şeş'ten korunmak için kurban kesme ve muska yazmaya ek olarak bir tılsım verilmiş, bu tılsım bir kâğıda yazılıp temiz suya bırakılması, ardından bu su ile gusül alınması istenmiștir: Bu țılsımı yaza șuya bıraǵa ol șuyla temįz yerde ġusl ide.

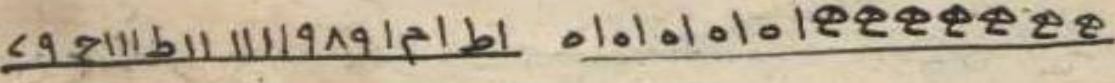

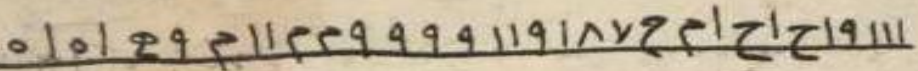

\section{Sonuç}

İnsanoğlunun bilinmez olana merakl ve gök cisimlerini kutsallaştırması, yıldızlara ve ayın hareketlerine göre birtakım tahminlerde bulunması dîv-nâmelerin yüzyıllardır geleneğimizde var olmasına zemin hazırlamıştır. Günümüzde burçlara göre hayatlarını şekillendiren, yapacakları eylemleri hesaplayanlar dahi vardır. Eski bir gelenek olan burçlar astroloji alanının yegâne unsurudur. İnanışlar bağlamında incelediğimiz eser, bahsi geçen burçlara mensup kişilerin, birtakım özelliklerinden ve yapacakları eylemlerin hayır yahut şer olduğundan bahsetmemekte, yalnızca insanlara kendilerine musallat olan cinlerden korunma yollarını vermektedir. Bu yönüyle diğer dîv-nâmelerden farklılık göstermektedir.

Hz. Süleyman Peygamber'in eserde çokça kendisine yer bulması ise dikkat çekici bir unsurdur. Çoğu yıldız-nâme metninin, yalnızca başında adı zikredilen Hz. Süleyman, incelenen eserde her bölümde başroldedir. Cinlerin efendisi olarak addedilen Süleyman Peygamber, bu eserde de her bir burcun perisine emirler vermektedir.

Eserde değinilmesi gereken başka bir unsur ise bahsi geçen burçların perilerinin isimleridir. Bu isimlere başka kaynaklarda rastlanılmamış, Firdevsînnin Tâli î Mevlûd'undan oldukça farklı olduğu tespit edilmiştir. Kurban edilen hayvanlar koyun, kuzu, tavuk, horoz ve oğlak olup, burçlara göre renkleri farklılık göstermektedir. Kimi zaman kara kimi zaman ak, kimi zamansa alaca renkli hayvanların kurban edilmesi emredilmiştir.

Perilerin verdiği zararlardan korunma yolları ve bu kötülükleri sağaltma yöntemleri ilgi çekicidir. Halk inanışlarına ters düşmeyen sağaltma yöntemlerinin -kurban kesme, kurban kanıyla muska yazma, şifalı duaların okunduğu sular ile yıkanma gibi- yanı sıra farklı bir metot da işlenmiștir. Kurban edilecek hayvanlarla birlikte tıpkı onlar gibi ses çıkarmanın gerekliliği vurgulanmış, bu eylem "afgurmak" terimi ile eserde kendisine yer bulmuştur. Bu durumun Şamanizm inancıyla ilintili olması muhtemeldir. Şamanların, kötü ruhlardan arınmak için yaptıkları ayinlerde hayvan seslerine benzer sesler çıkardıkları bilinen bir gerçektir. Eser bu yönüyle 
İslami anlayışla beraber İslamiyet öncesi inanışlara da değinmektedir. Ayrıca eserde kadın-erkek ayrımı bulunmamakta, eserin en başında "ister avrat olsun ister er kişi" şeklinde bir ibare geçmektedir.

Sonuç olarak kültürümüzde önemli bir yere sahip olan burçlar, incelenen eserde benzer türde yazılmış diğer eserlerde olduğundan farklı bir metotla incelenmiş ve halk inanışlarıyla özdeşleşmiştir. Yapılacak her eylemin ayetler eşliğinde sunulması, kurban kesme âdeti, koruyucu muskalar yazma inanışı bugün bile Anadolu'da yaygınca uygulanan geleneklerdendir.

\section{KAYNAKÇA}

Artun, E. (2006). Adana halk kültürü. Adana: Altın Koza.

Bekki, S. (1996). Türk mitolojisinde kurban. Akademik Araştırmalar, S. 3, 16-82.

Boratav, P. N. (1994). 100 soruda Türk folkloru. İstanbul: Gerçek.

Çatalbaş, R. (2011). Türklerde hayvan sembolizmi ve din ilişkisi. Turan Stratejik Araștırmalar Merkezi Dergisi, 3 (12), 49-60.

Demirci, K. (2006). Muska. İslam Ansiklopedisi, C. 31, 265-267, İstanbul: Türkiye Diyanet Vakfi.

Erciyas, O. (2010). 15. yy. astroloji eseri Kitâbu Esrâri'n-Nücûm ve Havvâs'ın Türk bilim dili ve astroloji - kronoloji terimleri açısından önemi. Sosyal Bilimler Araştırmaları Dergisi, S. 1, 45-58.

Güç, A. (2002). Kurban. İslam Ansiklopedisi, C. 26, 433-435, İstanbul: Türkiye Diyanet Vakfi.

Gür, N. (2012). Osmanlı fal geleneği bağlamında Yıldıznâme-i Falnâme ve Tâlinâme metinleri. Millî Folklor, S. 96, 202-215.

Kandemir. F. (2016). Halk inançlarının psiko-sosyal nedenleri ve Türkiye'deki halk inançlarının tarihi temelleri. Erzincan Üniversitesi Sosyal Bilimler Enstitüsü Dergisi, IX-I, 97-114.

Kutluer, İ. (1992). Burç. İslam Ansiklopedisi, C. 6, 422-424, İstanbul: Türkiye Diyanet Vakfi.

Sinmez, C.. - Aslım, G. (2017) İç Anadolu bölgesindeki hayvanlarla ilgili inanış ve uygulamalar üzerine bir değerlendirme. Bilig, S. 81, 205-232.

Şentürk, A. A. (1993). Klasik Osmanlı edebiyatı ışığında eski âdetler ve günlük hayattan sahneler II. Türk Dili, S. 500, 211-223. 
EK: Tıpkı Basım

$1 b$

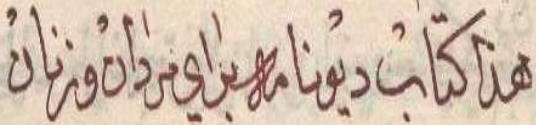

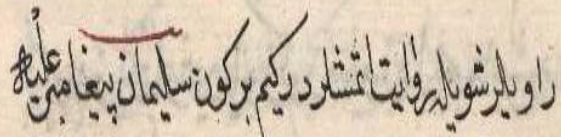

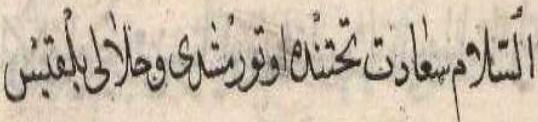

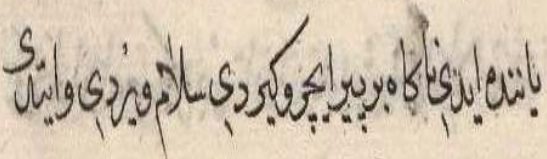

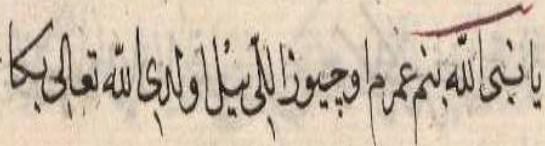

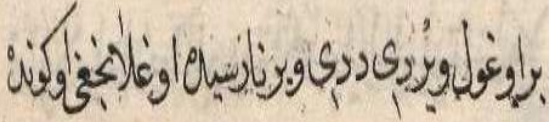
Y.3

$2 b$

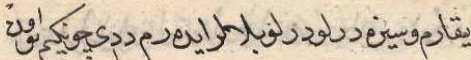

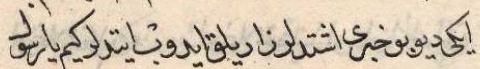

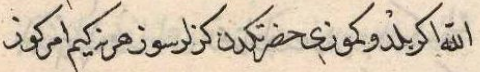
درالم

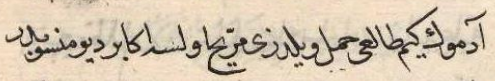

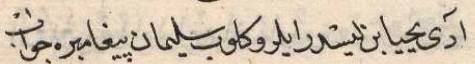

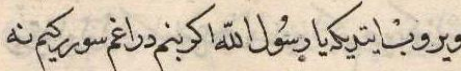

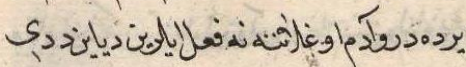

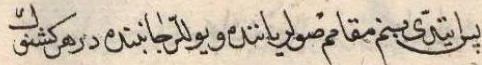

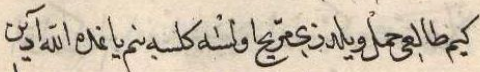

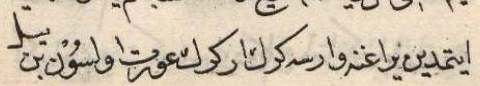
19.
$2 \mathrm{a}$

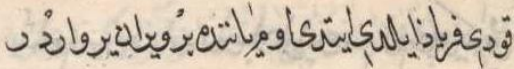

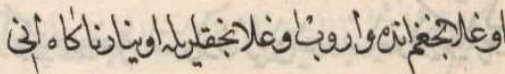

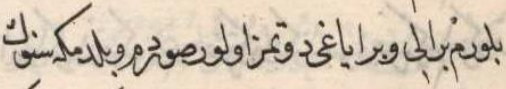

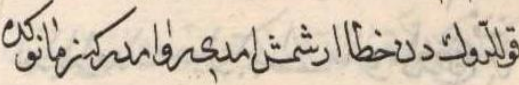

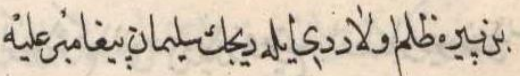

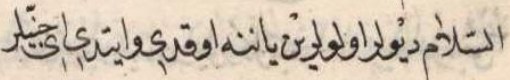

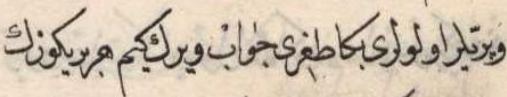
مناختف -

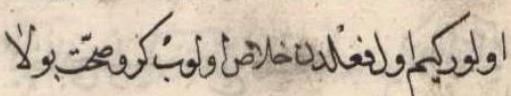

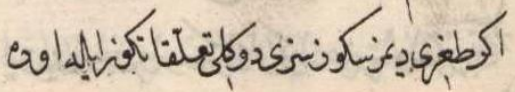

$3 a$

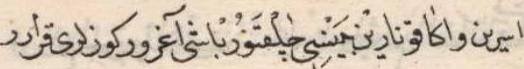

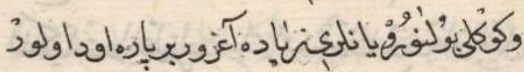

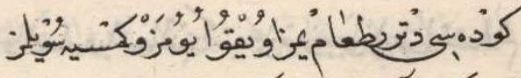

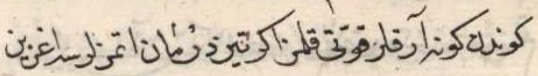

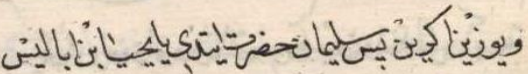

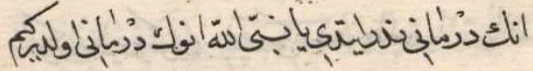

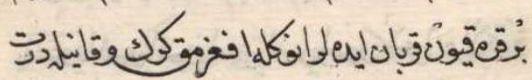

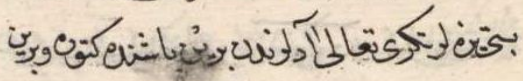

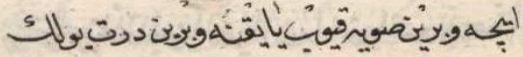

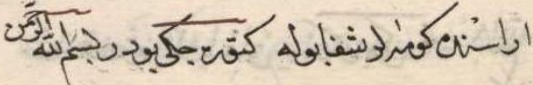

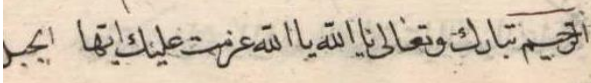




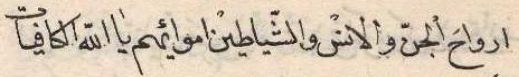

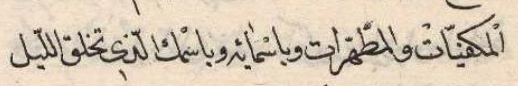

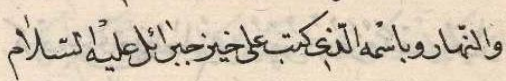

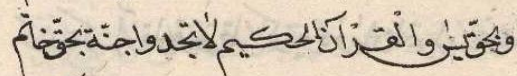

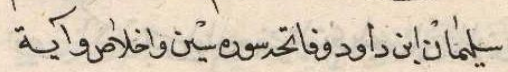

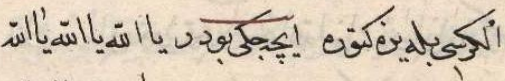

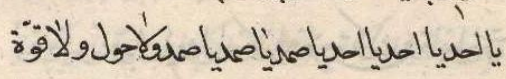

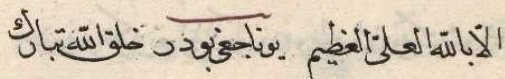

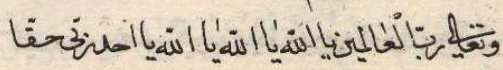

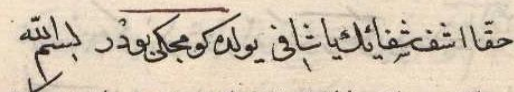

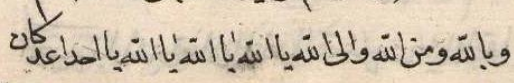
5

$4 b$

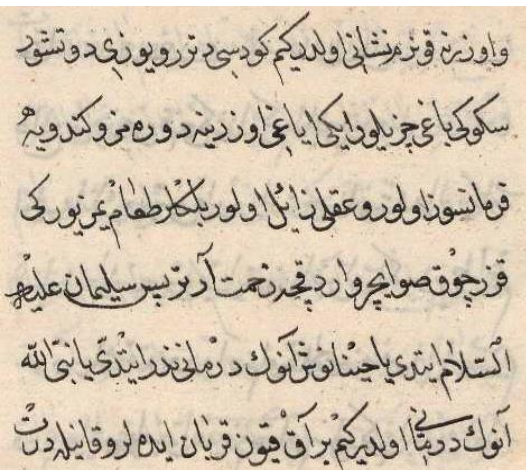

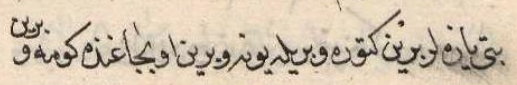

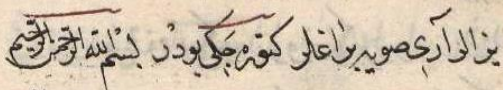

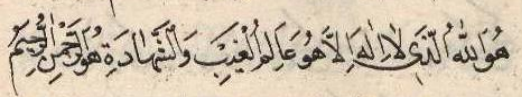
هُوَّة

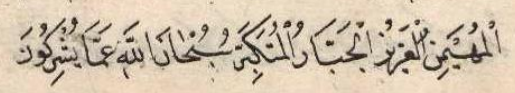

$4 a$

ح

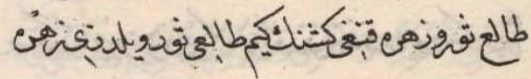

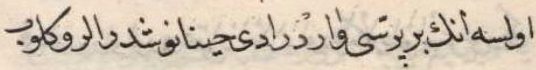

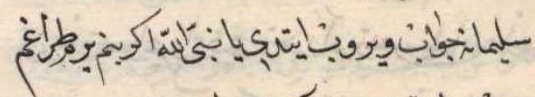

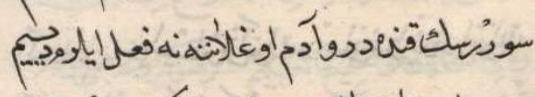

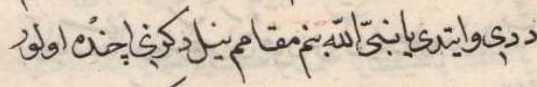

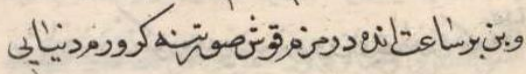

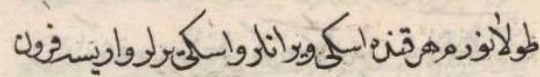

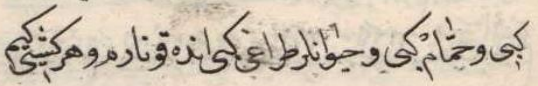

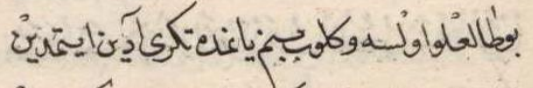

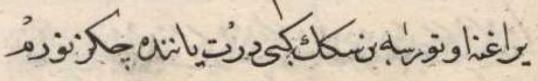

$5 a$

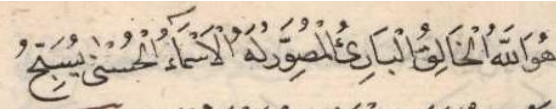

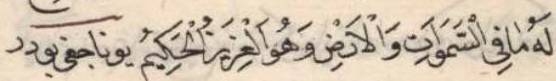

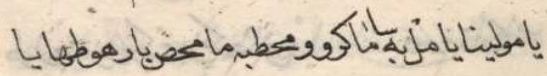

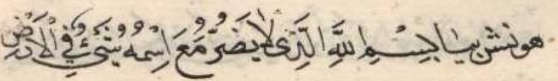

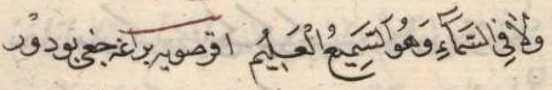

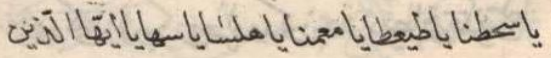

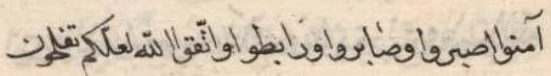

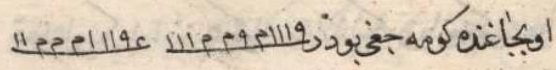

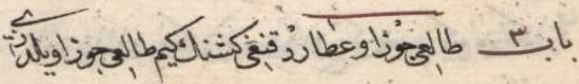

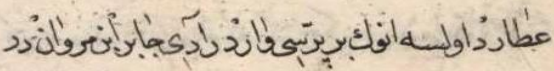

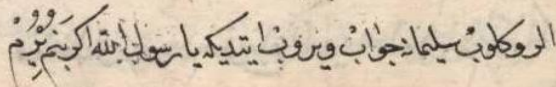




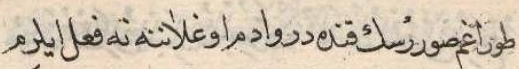

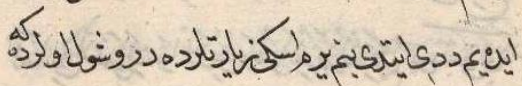

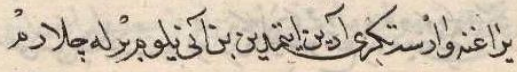

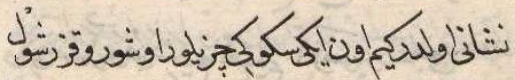

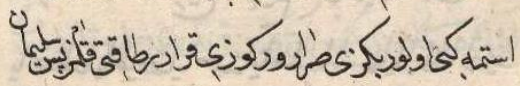

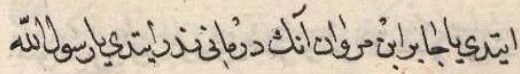

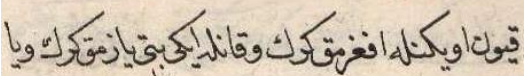

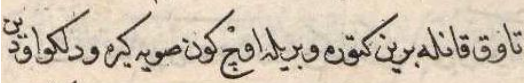

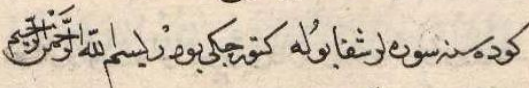

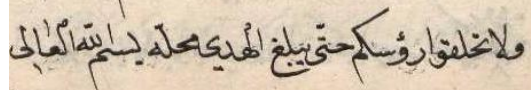

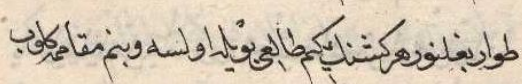

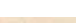

st

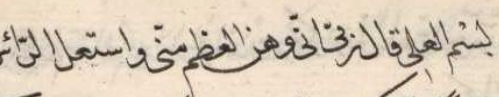

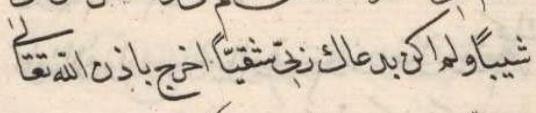

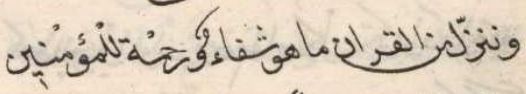

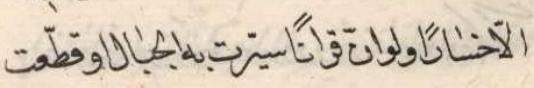

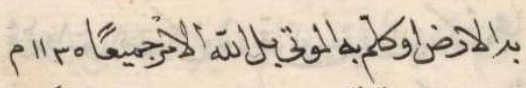


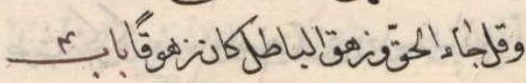

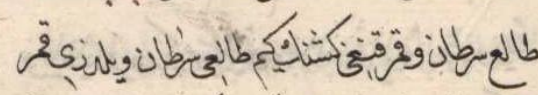

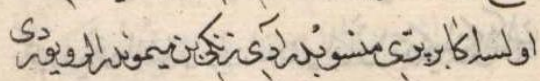

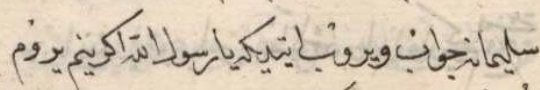

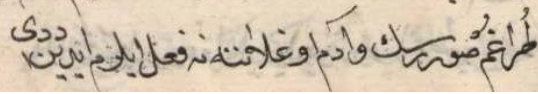

\section{$6 b$}

نr

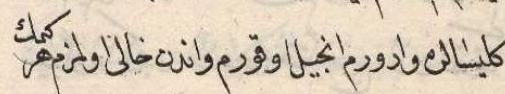

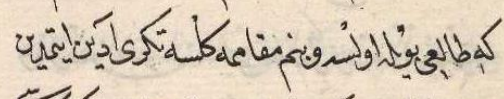

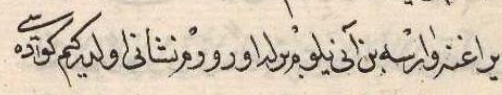

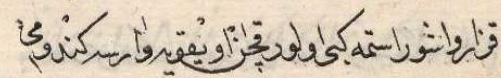

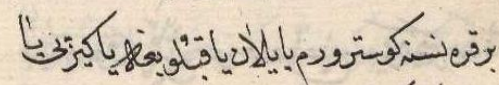

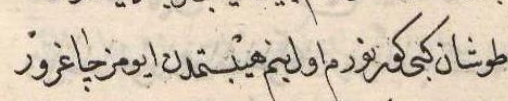

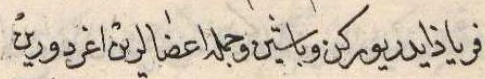

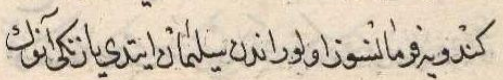

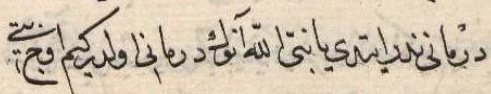

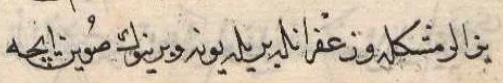
उ.
$7 a$

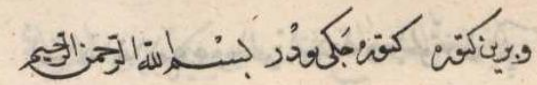

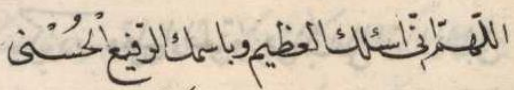

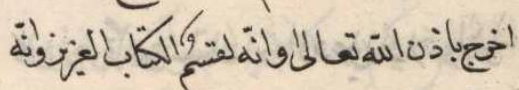

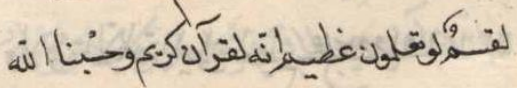

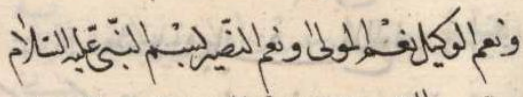

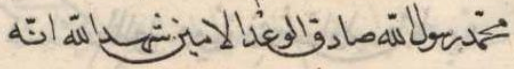

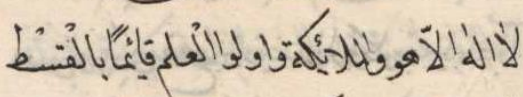

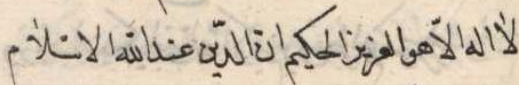

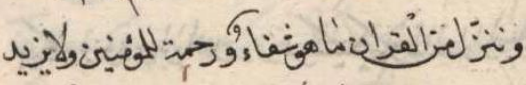

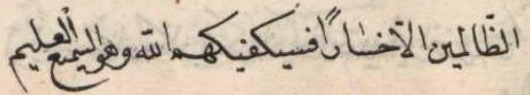

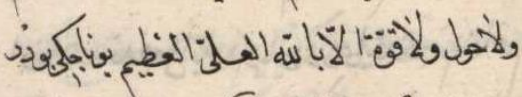




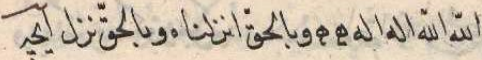

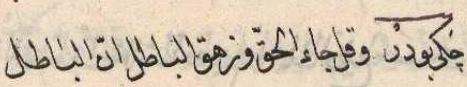

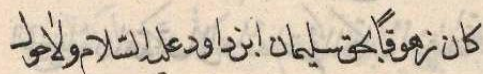

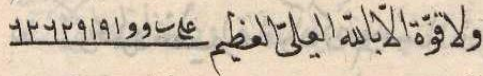

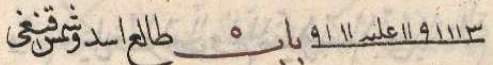

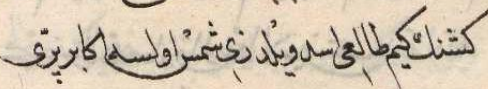

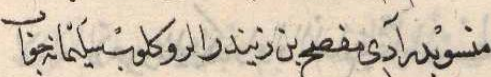

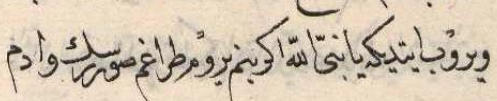

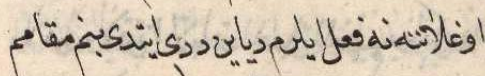

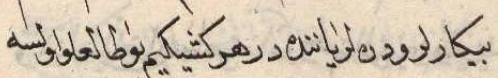

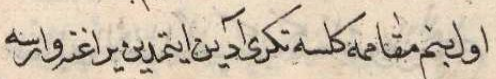

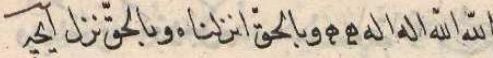
:

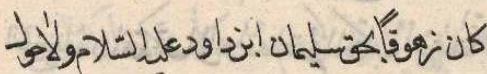

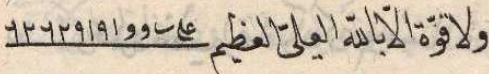

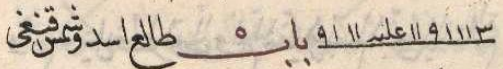

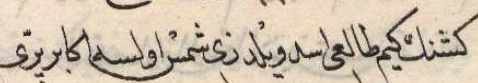

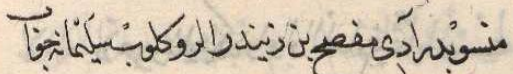

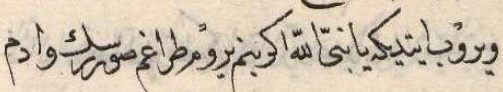

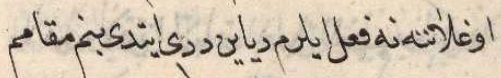

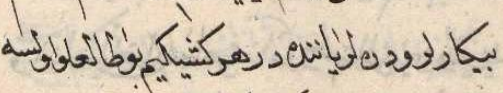

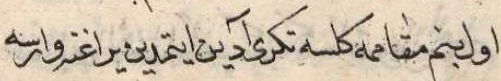

$8 b$

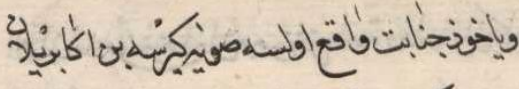

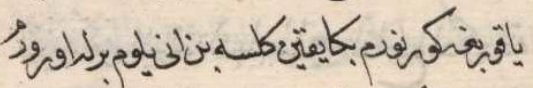

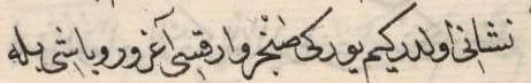

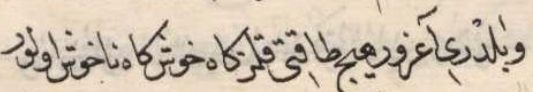
.

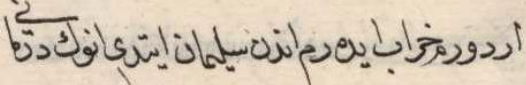

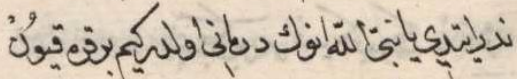

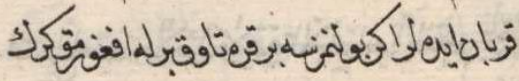

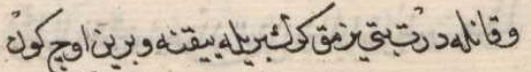

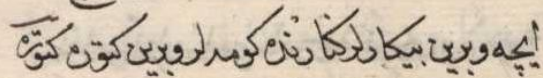

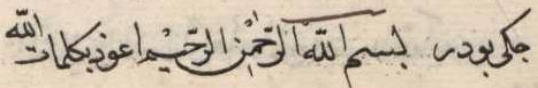

$9 a$

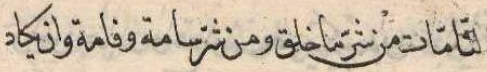

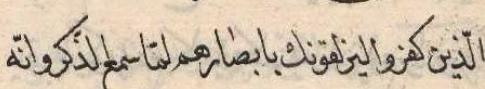

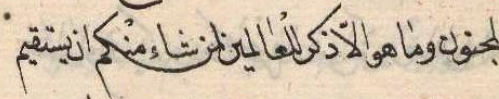

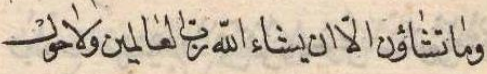

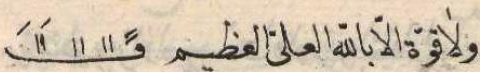
(1)

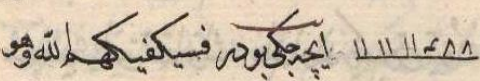
罗

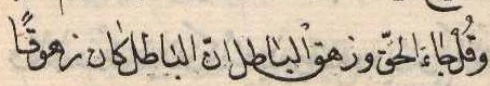
tin tris

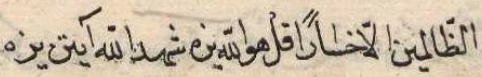




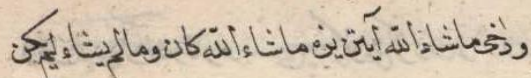

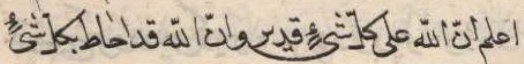

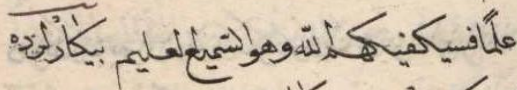

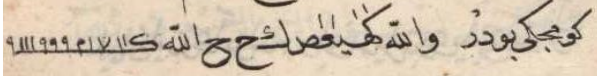
1

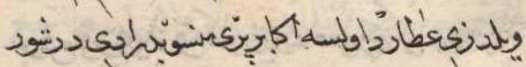

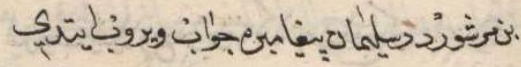

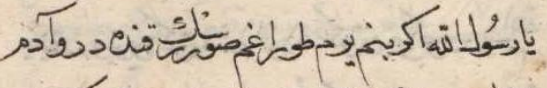

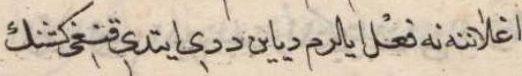

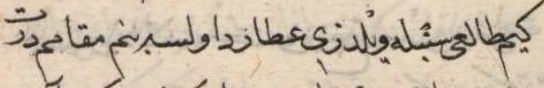

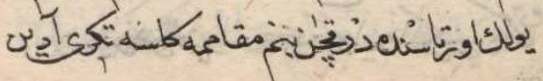

\section{$10 \mathrm{~b}$}

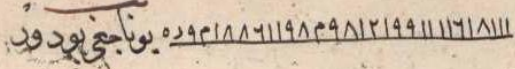

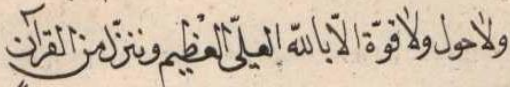

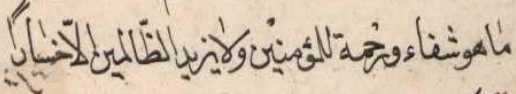

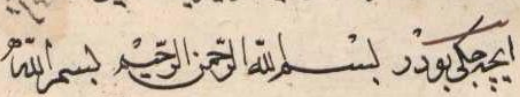

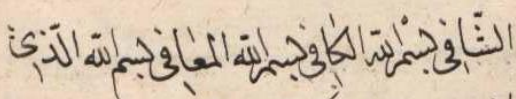

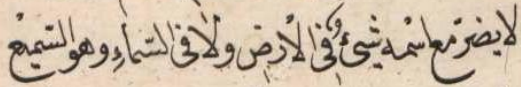

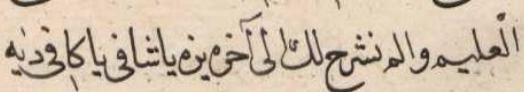

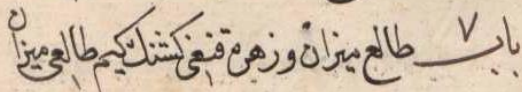

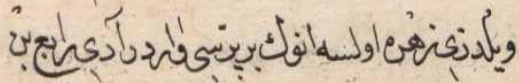

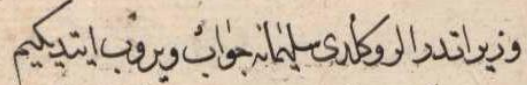

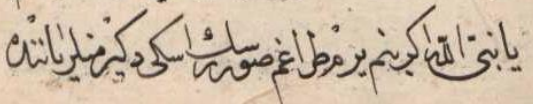

$11 \mathrm{a}$

والكان

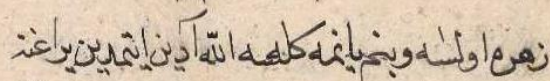

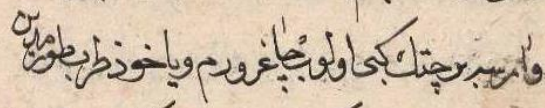

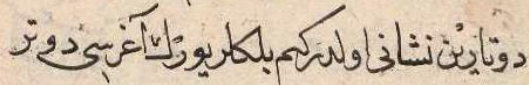

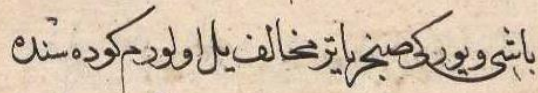

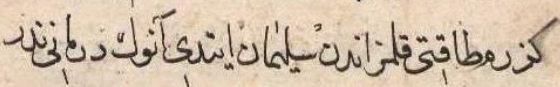

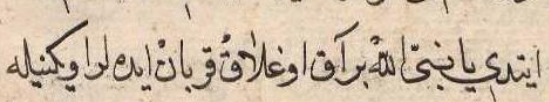

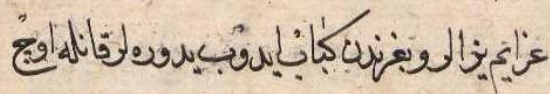

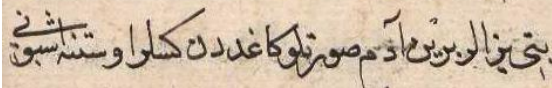

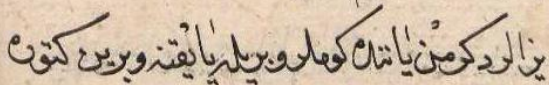

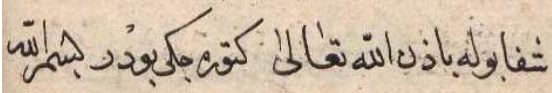




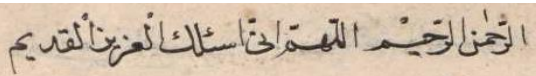

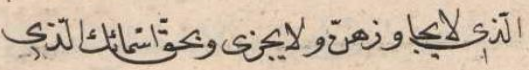

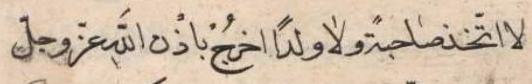

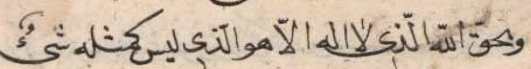

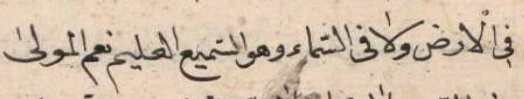

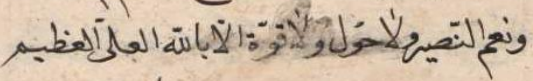

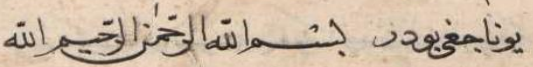

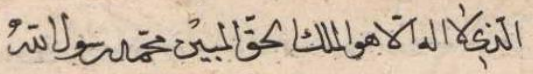

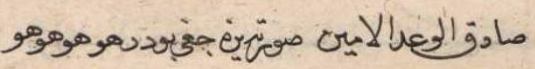

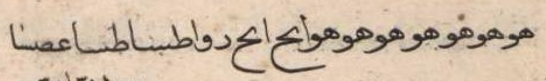
e

\section{.}

بإن 1

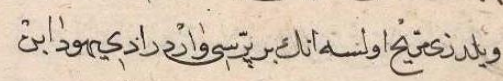

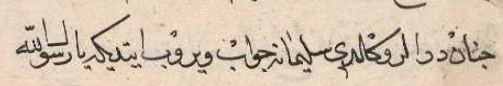

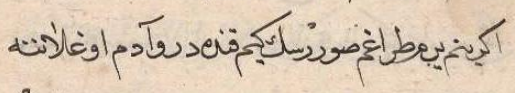
ند

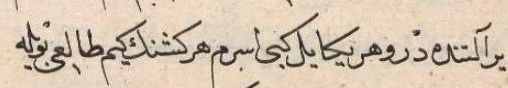

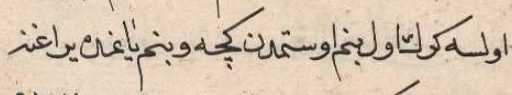

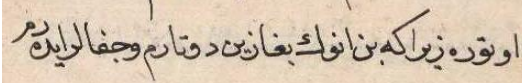

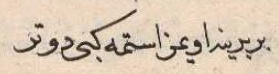

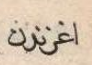

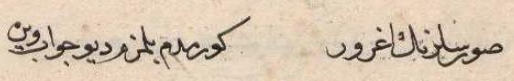

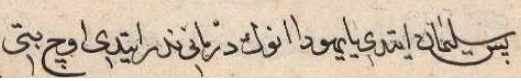

\section{$12 \mathrm{~b}$}

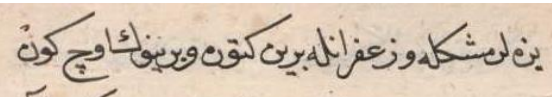

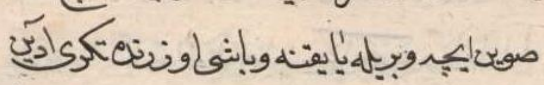

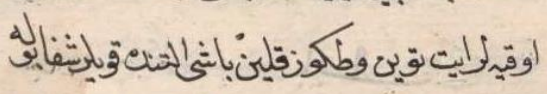

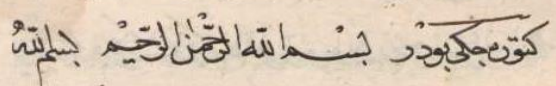

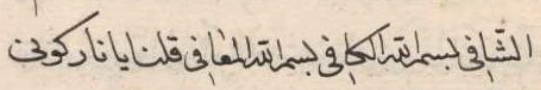

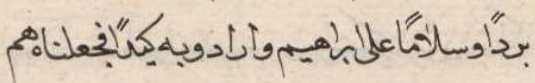

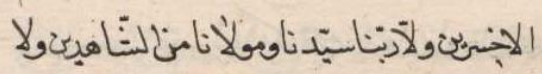

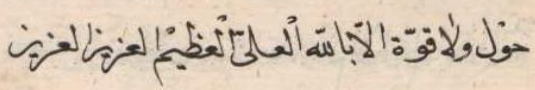

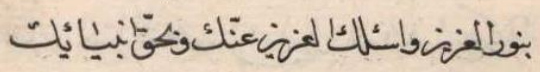

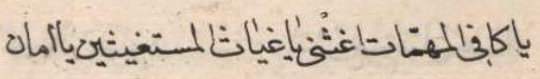

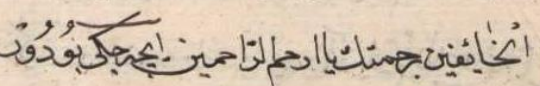

$13 a$

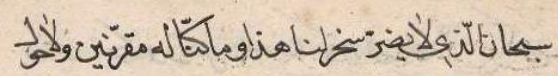

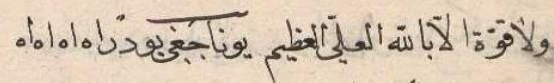

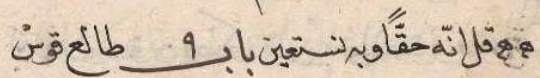

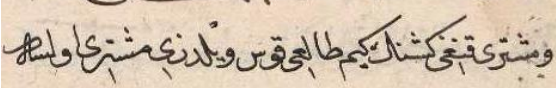

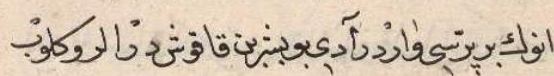

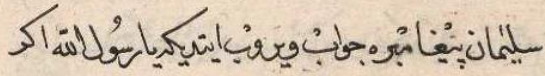

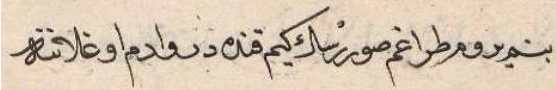

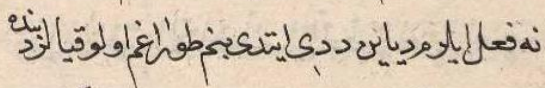

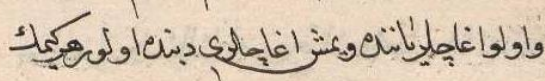

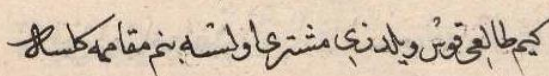

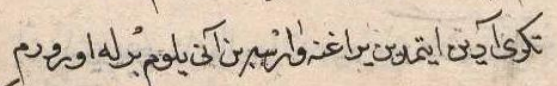




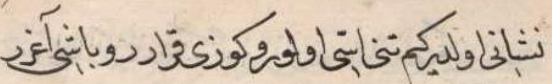

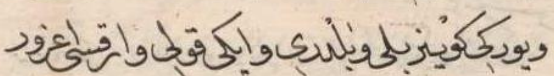

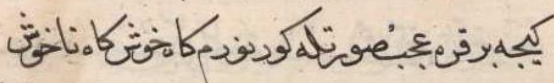

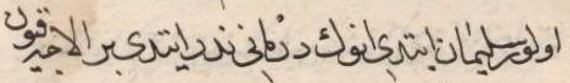

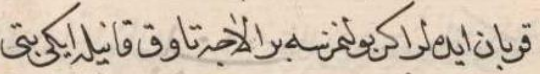

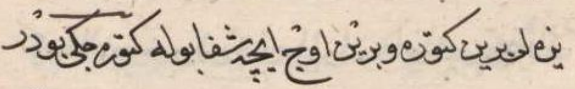

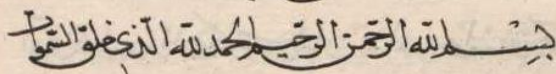

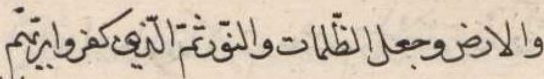

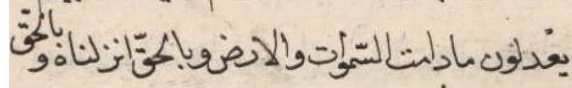

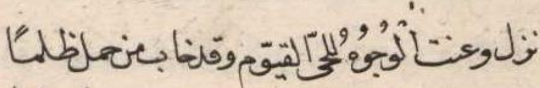

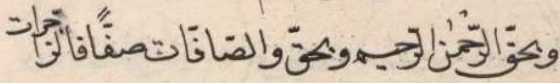

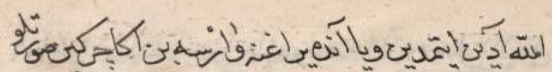

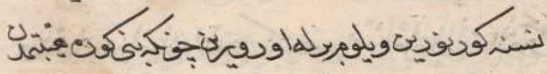

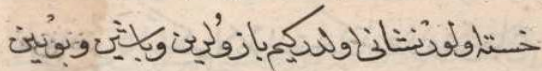

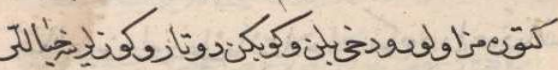

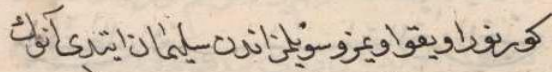
,

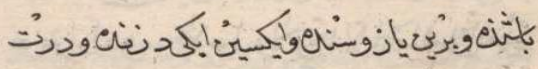

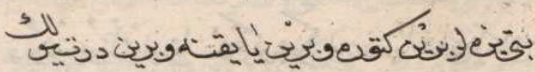

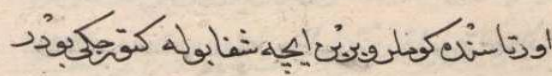

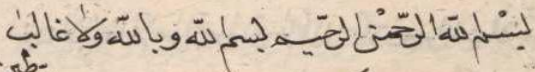

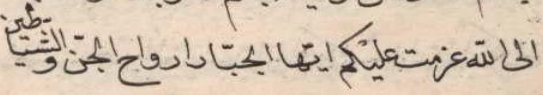

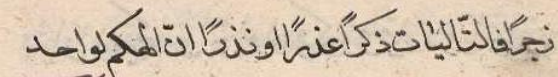

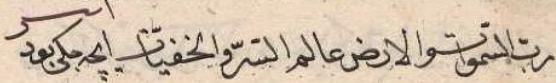

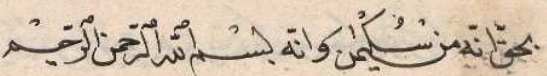

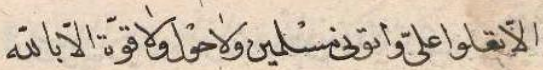

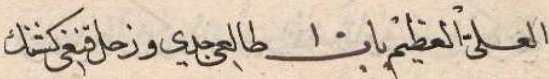

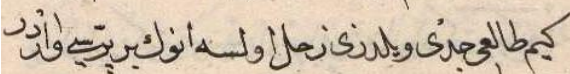

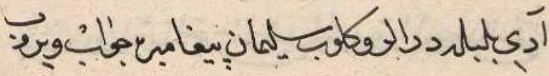

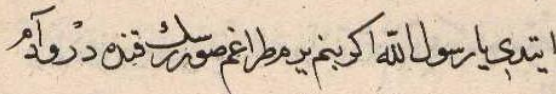

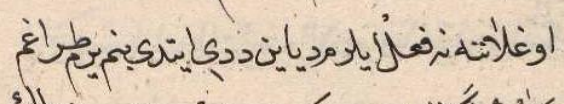

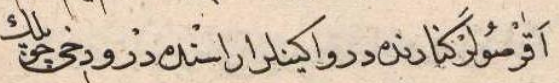

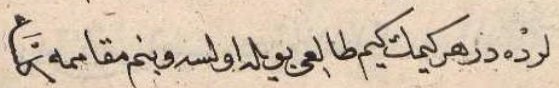

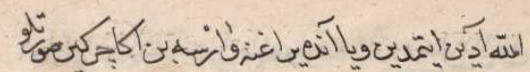

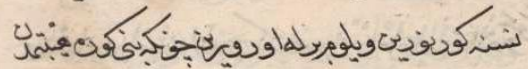

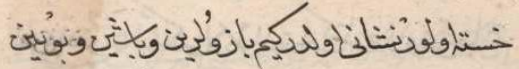

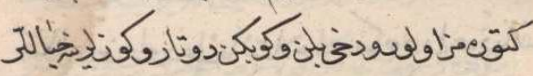

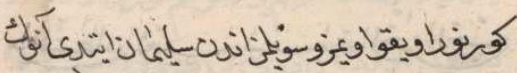
ن

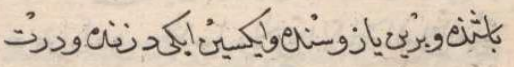

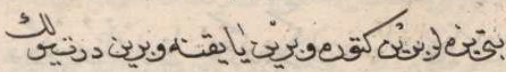

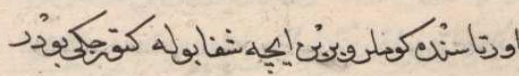

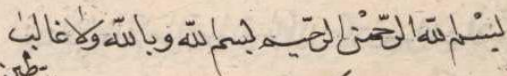

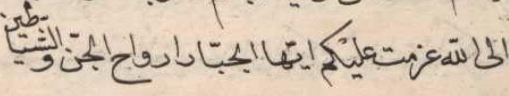




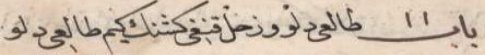

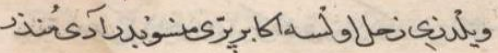

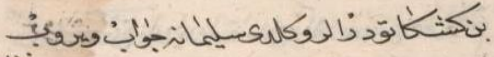

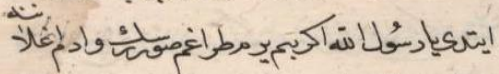

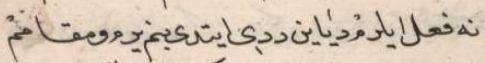

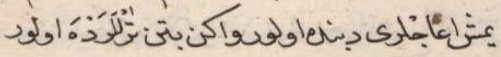

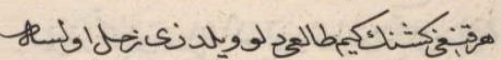

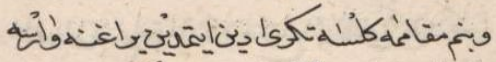

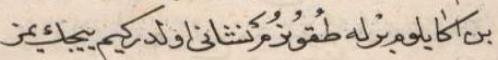
جل

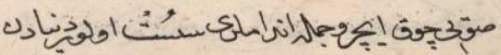

$16 \mathrm{~b}$

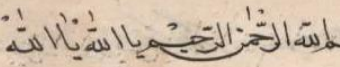
דis

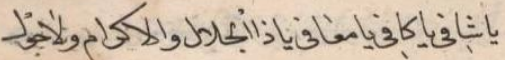

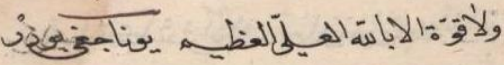

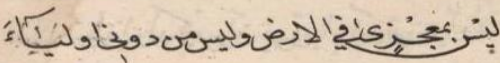

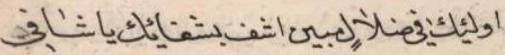

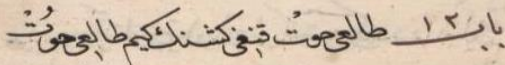
و و

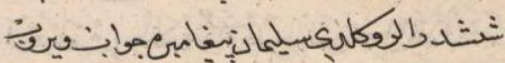

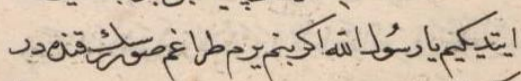

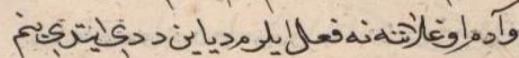

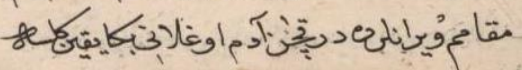

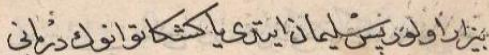

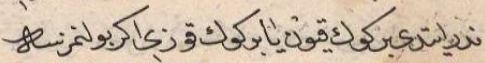

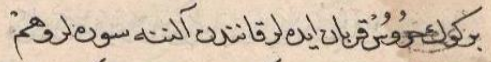

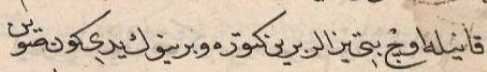

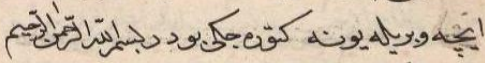
,

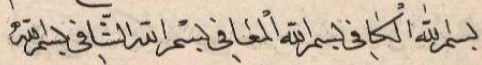

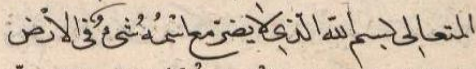

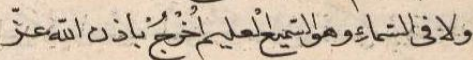

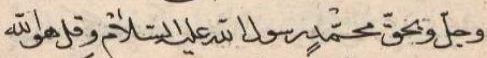

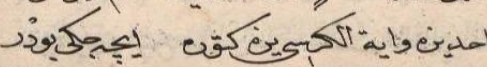

\section{$17 a$}

إن

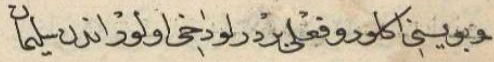

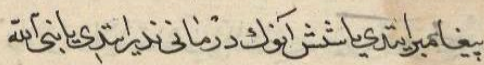

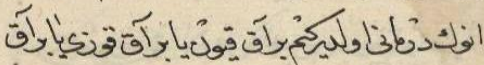

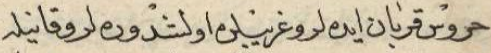

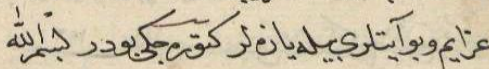

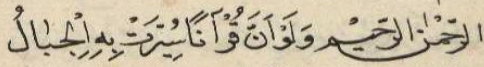

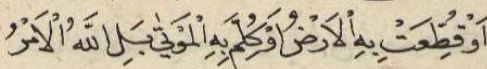

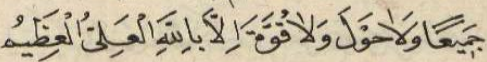

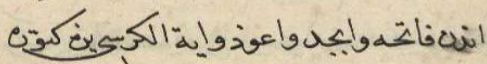

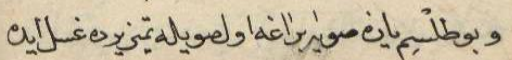

$17 b$

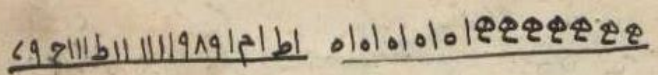

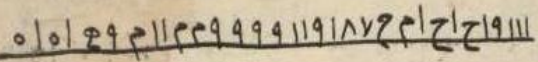

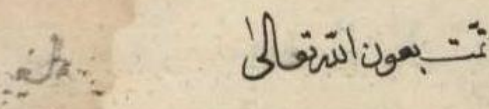

